\title{
Ineffective health control: concept analysis
}

\author{
Controle ineficaz da saúde: análise de conceito \\ Gestión ineficaz de la salud: análisis de concepto
}

Wenysson Noleto dos Santos'
ORCID: 0000-0002-2093-5415

Rudval Souza da Silva"

ORCID: 0000-0002-7991-8804

Francisca Marta de Lima Costa Souza' ORCID: 0000-0002-2442-9499

Rebecca Stefany da Costa Santos"' ORCID: 0000-0002-1191-0232

Izaque Cavalcanti de Oliveiralv ORCID: 0000-0002-1756-6495

Richardson Augusto Rosendo da Silva' ORCID: 0000-0001-6290-9365

'Universidade Federal do Rio Grande do Norte. Natal, Rio Grande do Norte, Brazil.

"Universidade do Estado da Bahia. Senhor do Bonfim,

Bahia, Brazil.

"'Universidade do Estado do Rio Grande do Norte. Mossoró, Rio Grande do Norte, Brazil.

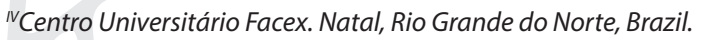

How to cite this article: Santos WN, Silva RS, Souza FMLC, Santos RSC, Oliveira IC, Silva RAR. Ineffective health control: concept analysis. Rev Bras Enferm. 2021;74(1):e20190158. doi: http://dx.doi.org/10.1590/0034-7167-2019-0158

Corresponding author:

Wenysson Noleto dos Santos

E-mail: wenysson-noleto@hotmail.com

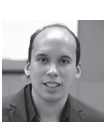

EDITOR IN CHIEF: Dulce Barbosa ASSOCIATE EDITOR: Elucir Gir

Submission: 05-12-2019

Approval: 09-05-2020

\begin{abstract}
Objectives: to identify and synthesize the concept of Ineffective Health Control. Methods: it is Concept Analysis from the perspective of Walker and Avant, operationalized by an integrative review in the databases Scopus, LILACS, PubMed, CINAHL, Web of Science, Science Direct e Cochrane, using the descriptors: Adhesion to Medication; Cooperation and Adherence to Treatment and Acquired Immunodeficiency Syndrome. Results: five critical attributes were identified for the concept, namely: patient's refusal to follow the therapeutic plan; abandoning treatment and worsening signs and symptoms; difficulty in reaching agreed goals; difficulty following health professionals' guidelines; multifactorial and dynamic process. Conclusions: the concept of Ineffective Health Control is characterized by a multifactorial and dynamic process evidenced by the patient's refusal to follow a therapeutic plan, favouring the abandonment of treatment and resulting in the worsening of signs and symptoms and failure to reach goals. Descriptors: Nursing Diagnosis; Cooperation and Adherence to Treatment; Concept Formation; Adhesion to Medication; Acquired Immunodeficiency Syndrome.
\end{abstract}

\section{RESUMO}

Objetivos: identificar e sintetizar o conceito de Controle Ineficaz da Saúde. Métodos: estudo de Análise de Conceito na perspectiva de Walker e Avant, desenvolvido a partir de uma revisão integrativa utilizando-se das bases de dados Scopus, LILACS, PubMed, CINAHL, Web of Science, Science Direct e Cochrane, com os descritores: Adesão à Medicação; Cooperação e Adesão ao Tratamento e Síndrome de Imunodeficiência Adquirida. Resultados: foram identificados cinco atributos críticos para o conceito, a saber: recusa do paciente em seguir o plano terapêutico; abandono do tratamento e agravamento de sinais e sintomas; dificul,,dade para alcançar metas pactuadas; dificuldade em seguir as orientações dos profissionais de saúde; processo multifatorial e dinâmico. Conclusões: o conceito Controle Ineficaz da Saúde se caracteriza por um processo multifatorial e dinâmico evidenciado pela recusa do paciente em seguir plano terapêutico, favorecendo o abandono do tratamento e tendo como consequências o agravamento de sinais e sintomas e não alcance das metas.

Descritores: Diagnóstico de Enfermagem; Cooperação e Adesão ao Tratamento; Formação de Conceito; Adesão à Medicação; Síndrome de Imunodeficiência Adquirida.

\section{RESUMEN}

Objetivos: identificar y sintetizar el concepto de Gestión Ineficaz de la Salud. Métodos: se trata de Análisis de Concepto en la perspectiva de Walker y Avant, operacionalizada por una revisión integrativa en las bases de datos Scopus, LILACS, PubMed, CINAHL, Web of Science, Science Direct e Cochrane, con los descriptores: Adherencia a la medicación; Cooperación y adherencia al tratamiento; $y$ síndrome de inmunodeficiencia adquirida. Resultados: han sido identificados cinco atributos críticos para el concepto, a saber: recusa del paciente en seguir el plan terapéutico; el abandono del tratamiento y la agravación de señales y síntomas; la dificultad para alcanzar metas pactadas; la dificultad en seguir las orientaciones de los profesionales de salud; el proceso multifactorial y dinámico. Conclusiones: el concepto Gestión Ineficaz de la Salud se caracteriza por un proceso multifactorial y dinámico evidenciado por la recusa del paciente en seguir el plan terapéutico, favoreciendo el abandono del tratamiento y teniendo como consecuencias la agravación de señales y síntomas y no alcance de las metas. Descriptores: Diagnóstico de Enfermería; Cooperación y Adhesión al Tratamiento; Formación de Concepto; Adhesión a la Medicación; Síndrome de Inmunodeficiencia Adquirida. 


\section{INTRODUCTION}

The acquired immunodeficiency syndrome (AIDS) corresponds to the most advanced phase of infection by the human immunodeficiency virus (HIV). Since its discovery, it presents itself as a global challenge related to epidemiological, sociocultural, family, economic and clinical aspects, characterizing the need to implement policies to face social and structural barriers for diagnosis and interventions, as well as discrimination and stigma associated with people living with HIV/AIDS (PLWHA). Worldwide, it is estimated that 37.9 million people live with the virus. In Brazil, from the beginning of the epidemic, from 1980 to June 2019, the number of diagnosed cases is 966,058 , with an annual record of an average of 39 thousand new cases in the last five years ${ }^{(1)}$.

It is known that AIDS imposes changes in lifestyle, which are related to the beliefs and behaviors learned and incorporated by people in social life. Therefore, it is undeniable that the health control of PLWHA is not limited only to the approach of the sick body, it is also necessary to consider life experience and subjectivity as essential aspects in the process of becoming ill and taking care of oneself.

The diagnosis of "Ineffective Health Control" is present in NANDA-I Taxonomy II in Domain 1 - Health Promotion, Class 2 - Health Control. It is defined as "Standard of regulation and integration into the daily life of a therapeutic regimen for disease treatment and its aftermath which is unsatisfactory to achieve specific health goals"(2). However, it is clear that there are gaps regarding its defining characteristics in relation to the PLWHA population.

Thus, the professionals involved in assisting PLWHA, especially nurses, need to understand that the interventions are complex and aim to favor the patient's self-control of health. It is important that nurses make sure that the patient understands the information received and how much it takes into account, promoting ways to raise awareness regarding the positive results of treatment in order to avoid ineffective health control. In this context, the nurse must use cognitive ability, their scientific knowledge, clinical reasoning and practical experience to assess the clinical manifestations presented by the individual, identifying the Nursing Diagnoses (ND) in order to direct nursing interventions for adequate assistance.

To this end, concept analysis was used as a methodological resource that aims to examine the basic elements of a concept, assist in the definition of obscure concepts, in addition to allowing the construction of hypotheses that accurately reflect the relationships between the concepts. Although the diagnoses proposed by NANDA-I are well recognized and applied in several clinical settings, it is understood that there are limitations in their definition in specific areas (eg, PLWHA), which justifies developing studies in search of accuracy. diagnosis and conceptual refinement to define appropriate nursing interventions; furthermore, it becomes possible to bring visibility to nursing as a science.

With that, the need arose to know new clinical indicators for the nursing diagnosis "Ineffective Health Control", applied to PLWHAs, through the following questions: What are the clinical indicators that characterize Ineffective Health Control in people living with AIDS? What are the factors that precede Ineffective
Health Control and its consequences in people living with AIDS?

Thus, it is essential to clarify new clinical indicators that provide greater evidence and theoretical support to assist the nursing practice directed to the diagnosis Ineffective Health Control in PLWHA.

\section{OBJECTIVES}

To identify and synthesize the concept of Ineffective Health Control.

\section{METHODS}

\section{Ethical aspects}

In the present study, we used the literature available in databases. Thus, there was no need for an appraisal by an Ethics and Research Committee, understanding that it is material in the public domain and that does not directly involve human beings.

\section{Study type}

Concept Analysis study, following the theoretical and methodological framework of Walker and Avant ${ }^{(3)}$, which comprises eight stages, namely: selection of the concept; determination of the objectives of the conceptual analysis; identification of possible uses of the concept; determination of defining attributes; identification of a model case; identification of additional cases; identification of the antecedents and consequences of the concept; and definition of empirical references ${ }^{(4)}$. The analysis was made operational through an integrative literature review according to Whittemore and Knalf ${ }^{(5)}$, which allowed the systematization of the knowledge produced on the studied concept.

The steps consisted of identifying the research question, searching the databases, evaluation, analysis of results, analyzing the results and presenting the review in order to support the conceptual analysis. For this stage of the review, the following research questions were elaborated: What are the clinical indicators that characterize Ineffective Health Control in the population at risk of PLWHA? What are the antecedents (related factors) and respective consequences (defining characteristics) of Ineffective Health Control?(4)

\section{Data collection and organization}

The search was carried out by the researcher from January to March 2018, through access to the CAPES portal in the following databases: Scopus, Web of Science, Cumulative Index to Nursing \& Allied Health Literature (CINAHL), National Library of Medicine and National Institutes of Health (PubMed), Science Direct, Cochrane and Latin American and Caribbean Literature in Health Sciences (LILACS).

The search was carried out in an uncontrolled way, using descriptors indexed in the MeSH (Medical Subject Headings) and DeCS (Health Sciences Descriptors), in Portuguese, English and Spanish: Adherence to Medication, Cooperation and Adherence to Treatment, Acquired Immunodeficiency Syndrome, with the 
following crossings on all bases: Adherence to Medication AND Cooperation and Adherence to Treatment; Acquired Immunodeficiency Syndrome AND Cooperation and Adherence to Treatment; Adherence to Medication AND Acquired Immunodeficiency Syndrome. The Boolean AND operator was used. The crossings were carried out equally in all databases.

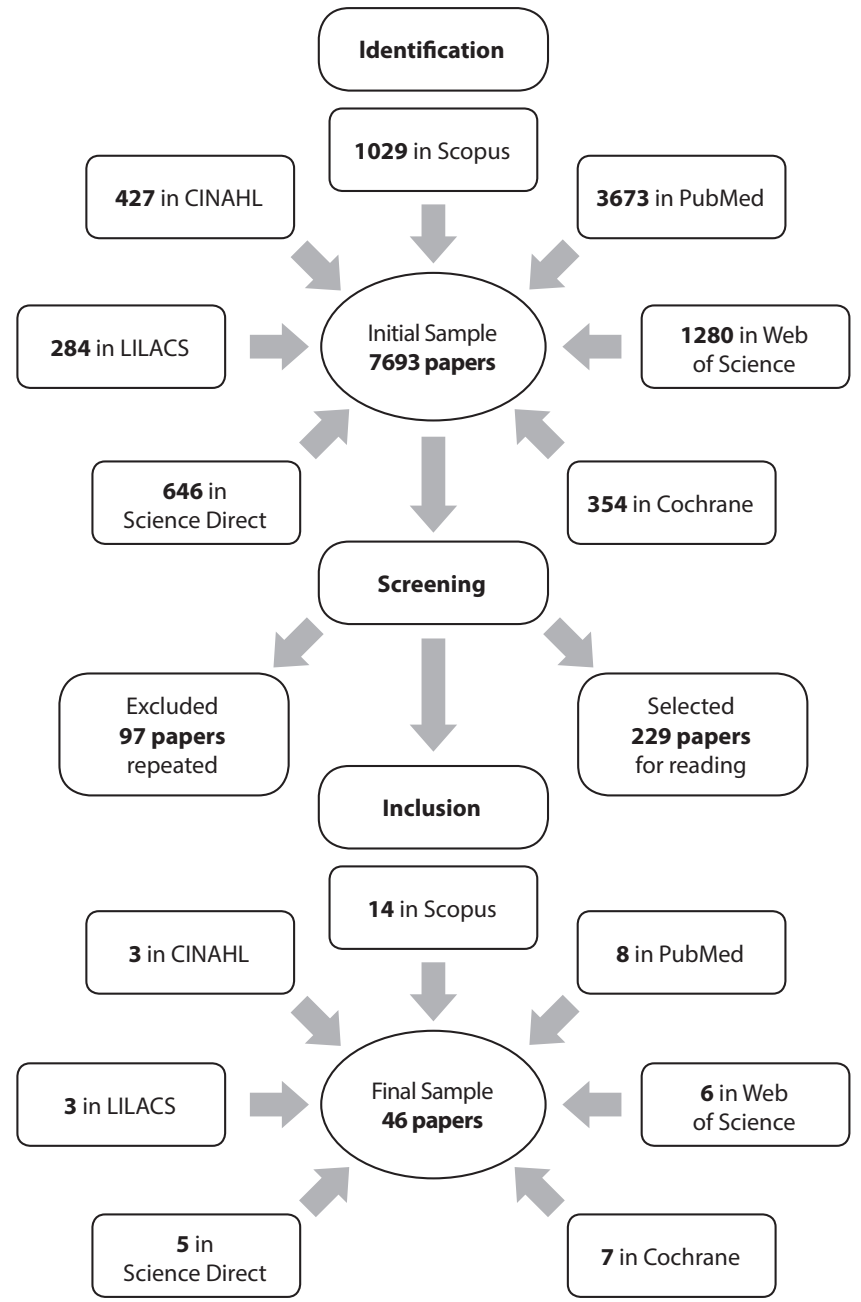

Figure 1 - Flowchart of the article selection process ${ }^{(4)}$, Brazil, 2020

The initial sample consisted of 7,693 articles as shown in Figure 1. Then, the selection criteria were applied to refine the search, namely: articles available in full, in Portuguese, English or Spanish and studies that answer the guiding questions. And the exclusion criteria: preliminary notes, protocols, ongoing research, reviews, editorials and letters to the editor. As it is a concept analysis that seeks to apprehend scientific evidence regarding the definitions and concepts about the studied phenomenon, the inclusion of studies of systematic reviews was admitted, considering that their exclusion could cause a significant reduction of significant information.

After applying the established criteria, the articles were subjected to reading the title and abstract for the selection of the first sample $(n=229)$. Then, to confirm the presence of the elements that supported the concept analysis, this sample was read in its entirety, so that it resulted in a final sample of 46 articles.

\section{RESULTS}

In relation to the 46 selected studies on the concept of Ineffective Health Control, the field of action that most prevailed was that of medicine (52.2\%), followed by nursing (17.4\%), public health (15.2\%), multidisciplinary (10.9\%) and biological sciences (4.3\%). Regarding the design of the studies, there was a predominance of descriptive (76.1\%), followed by cohort or case control studies (15.2\%), randomized clinical trials (6.5\%) and, to a lesser extent, reviews systematic (2.2\%). Most studies involved the adult population (95.6\%), followed by adolescents (2.2\%) and children (2.2\%). Chart 1 presents the synthesis of the studies.

Chart 1 - Summary of studies included in the integrative review phase $(\mathrm{N}=46)^{(4)}, 2020$

\begin{tabular}{|c|c|c|c|}
\hline Studies & $\begin{array}{l}\text { Year/Country/ } \\
\text { Database/Area }\end{array}$ & $\begin{array}{l}\text { Type of Study } \\
\text { / Level of } \\
\text { Evidence (LE) }\end{array}$ & Concept attributes \\
\hline$E 1^{(6)}$ & $\begin{array}{l}\text { 2018/Ghana/ } \\
\text { Scopus/I }\end{array}$ & $\begin{array}{l}\text { Descriptive } \\
\quad \mathrm{LE}=6\end{array}$ & $\begin{array}{l}\text { Difficulty in reaching } \\
\text { goals agreed between } \\
\text { the person and the health } \\
\text { professional }\end{array}$ \\
\hline$E 2^{(7)}$ & $\begin{array}{l}\text { 2018/Ethiopia/ } \\
\text { Scopus/II }\end{array}$ & $\begin{array}{c}\text { Longitudinal } \\
\text { cohort } \\
\mathrm{LE}=3\end{array}$ & $\begin{array}{l}\text { Patient's refusal to follow } \\
\text { the therapeutic plan }\end{array}$ \\
\hline $\mathrm{E}^{3(8)}$ & $\begin{array}{l}\text { 2017/Swaziland/ } \\
\text { Scopus/I }\end{array}$ & $\begin{array}{l}\text { Descriptive } \\
\quad \mathrm{LE}=6\end{array}$ & $\begin{array}{l}\text { Abandonment of } \\
\text { treatment leading to } \\
\text { ineffective results and } \\
\text { worsening of symptoms }\end{array}$ \\
\hline$E 4^{(9)}$ & $\begin{array}{l}\text { 2017/India/ } \\
\text { PubMed/I }\end{array}$ & $\begin{array}{c}\text { Cross } \\
\text { sectional } \\
\mathrm{LE}=6\end{array}$ & $\begin{array}{l}\text { Patient's refusal to follow } \\
\text { the therapeutic plan }\end{array}$ \\
\hline$E 5^{(10)}$ & $\begin{array}{l}\text { 2017/South } \\
\text { Africa/PubMed/II }\end{array}$ & $\begin{array}{c}\text { Descriptive } \\
\text { study } \\
\text { LE }=6\end{array}$ & $\begin{array}{l}\text { Patient's refusal to follow } \\
\text { the therapeutic plan }\end{array}$ \\
\hline$E 6^{(11)}$ & $\begin{array}{l}\text { 2017/United } \\
\text { Kingdom/ } \\
\text { Cochrane/l }\end{array}$ & $\begin{array}{l}\text { Systematic } \\
\text { review } \\
\mathrm{LE}=1\end{array}$ & $\begin{array}{l}\text { Abandonment of } \\
\text { treatment leading to } \\
\text { ineffective results and } \\
\text { worsening of symptoms }\end{array}$ \\
\hline$E 7^{(12)}$ & $\begin{array}{l}\text { 2017/Zambia/ } \\
\text { Scopus/III }\end{array}$ & $\begin{array}{l}\text { Cross } \\
\text { sectional } \\
\mathrm{LE}=6\end{array}$ & $\begin{array}{l}\text { Difficulty in reaching } \\
\text { goals agreed between } \\
\text { the person and the health } \\
\text { professional }\end{array}$ \\
\hline$E 8^{(13)}$ & $\begin{array}{l}\text { 2017/Uganda/ } \\
\text { Scopus/II }\end{array}$ & $\begin{array}{l}\text { Descriptive } \\
\quad \mathrm{LE}=6\end{array}$ & $\begin{array}{l}\text { Patient's refusal to follow } \\
\text { the therapeutic plan }\end{array}$ \\
\hline$E 9^{(14)}$ & $\begin{array}{l}\text { 2016/Burkina } \\
\text { Faso/Scopus/II }\end{array}$ & $\begin{array}{l}\text { Cross } \\
\text { sectional } \\
\mathrm{LE}=6\end{array}$ & $\begin{array}{l}\text { Abandonment of } \\
\text { treatment leading to } \\
\text { ineffective results and } \\
\text { worsening of symptoms }\end{array}$ \\
\hline E10 $0^{(15)}$ & $\begin{array}{l}2016 / \\
\text { Netherlands/ } \\
\text { PubMed/II }\end{array}$ & $\begin{array}{l}\text { Cross } \\
\text { sectional } \\
\mathrm{LE}=6\end{array}$ & $\begin{array}{l}\text { Difficulty in reaching } \\
\text { goals agreed between } \\
\text { the person and the health } \\
\text { professional }\end{array}$ \\
\hline $\mathrm{E} 11^{(16)}$ & $\begin{array}{l}\text { 2016/USA/ } \\
\text { PubMed/II }\end{array}$ & $\begin{array}{l}\text { Descriptive } \\
\quad \mathrm{LE}=6\end{array}$ & $\begin{array}{l}\text { Abandonment of } \\
\text { treatment leading to } \\
\text { ineffective results and } \\
\text { worsening of symptoms }\end{array}$ \\
\hline $\mathrm{E} 12^{(17)}$ & $\begin{array}{l}\text { 2015/Vietnam/ } \\
\text { PubMed/III }\end{array}$ & $\begin{array}{l}\text { Cross } \\
\text { sectional } \\
\mathrm{LE}=6\end{array}$ & $\begin{array}{l}\text { Abandonment of } \\
\text { treatment leading to } \\
\text { ineffective results and } \\
\text { worsening of symptoms }\end{array}$ \\
\hline
\end{tabular}


Chart 1

\begin{tabular}{|c|c|c|c|}
\hline Studies & $\begin{array}{l}\text { Year/Country/ } \\
\text { Database/Area }\end{array}$ & $\begin{array}{l}\text { Type of Study } \\
\text { / Level of } \\
\text { Evidence (LE) }\end{array}$ & Concept attributes \\
\hline $\mathrm{E} 13^{(18)}$ & $\begin{array}{l}\text { 2015/USA/ } \\
\text { PubMed/II }\end{array}$ & $\begin{array}{l}\mathrm{RCT}^{*} \\
\mathrm{LE}=2\end{array}$ & $\begin{array}{l}\text { Difficulty in reaching } \\
\text { goals agreed between } \\
\text { the person and the health } \\
\text { professional }\end{array}$ \\
\hline $\mathrm{E} 14^{(19)}$ & $\begin{array}{l}\text { 2015/South } \\
\text { Africa/PubMed/III }\end{array}$ & $\begin{array}{l}\text { Descriptive } \\
\qquad \mathrm{LE}=6\end{array}$ & $\begin{array}{l}\text { Difficulty in reaching } \\
\text { goals agreed between } \\
\text { the person and the health } \\
\text { professional }\end{array}$ \\
\hline $\mathrm{E} 15^{(20)}$ & $\begin{array}{l}\text { 2015/Australia/ } \\
\text { PubMed/IV }\end{array}$ & $\begin{array}{l}\text { Descriptive } \\
\qquad \mathrm{LE}=6\end{array}$ & $\begin{array}{l}\text { Difficulty in reaching } \\
\text { goals agreed between } \\
\text { the person and the health } \\
\text { professional }\end{array}$ \\
\hline $\mathrm{E} 16^{(21)}$ & $\begin{array}{l}\text { 2015/USA/ } \\
\text { Scopus/N }\end{array}$ & $\begin{array}{l}\text { Cross } \\
\text { sectional } \\
\text { LE }=6\end{array}$ & $\begin{array}{l}\text { Patient's refusal to follow } \\
\text { the therapeutic plan }\end{array}$ \\
\hline $\mathrm{E} 17^{(22)}$ & $\begin{array}{l}\text { 2014/Tanzania/ } \\
\text { Scopus/V }\end{array}$ & $\begin{array}{l}\text { Cohort } \\
\mathrm{LE}=3\end{array}$ & $\begin{array}{l}\text { Abandonment of } \\
\text { treatment leading to } \\
\text { ineffective results and } \\
\text { worsening of symptoms }\end{array}$ \\
\hline $\mathrm{E} 18^{(23)}$ & $\begin{array}{l}\text { 2014/Brazil/ } \\
\text { LILACS/II }\end{array}$ & $\begin{array}{l}\text { Cross } \\
\text { sectional } \\
\text { LE }=6\end{array}$ & $\begin{array}{l}\text { Patient's refusal to follow } \\
\text { the therapeutic plan }\end{array}$ \\
\hline E19(24) & $\begin{array}{l}\text { 2017/Brazil/ } \\
\text { Scopus/II }\end{array}$ & $\begin{array}{l}\text { Cross } \\
\text { sectional } \\
\text { LE }=6\end{array}$ & $\begin{array}{l}\text { Patient's refusal to follow } \\
\text { the therapeutic plan }\end{array}$ \\
\hline $\mathrm{E} 20^{(25)}$ & $\begin{array}{l}\text { 2016/Brazil/ } \\
\text { LILACS/IV }\end{array}$ & $\begin{array}{l}\text { Cross } \\
\text { sectional } \\
\text { LE }=6\end{array}$ & $\begin{array}{l}\text { Patient's refusal to follow } \\
\text { the therapeutic plan }\end{array}$ \\
\hline$E 21^{(26)}$ & $\begin{array}{l}\text { 2017/USA/Web } \\
\text { of Science/II }\end{array}$ & $\begin{array}{l}\text { Cross } \\
\text { sectional } \\
\text { LE }=6\end{array}$ & $\begin{array}{l}\text { Abandonment of } \\
\text { treatment leading to } \\
\text { ineffective results and } \\
\text { worsening of symptoms }\end{array}$ \\
\hline $\mathrm{E} 22^{(27)}$ & $\begin{array}{l}\text { 2017/Ethiopia/ } \\
\text { Web of Science/II }\end{array}$ & $\begin{array}{l}\text { Cohort } \\
\mathrm{LE}=3\end{array}$ & $\begin{array}{l}\text { Patient's refusal to follow } \\
\text { the therapeutic plan }\end{array}$ \\
\hline$E 23^{(28)}$ & $\begin{array}{l}\text { 2017/Nigeria/ } \\
\text { Web of Science/II }\end{array}$ & $\begin{array}{l}\text { Descriptive } \\
\qquad \mathrm{LE}=6\end{array}$ & $\begin{array}{l}\text { Abandonment of } \\
\text { treatment leading to } \\
\text { ineffective results and } \\
\text { worsening of symptoms }\end{array}$ \\
\hline$E 24^{(29)}$ & $\begin{array}{l}\text { 2018/USA/Web } \\
\text { of Science/II }\end{array}$ & $\begin{array}{l}\text { Cross } \\
\text { sectional } \\
\text { LE }=6\end{array}$ & $\begin{array}{l}\text { Abandonment of } \\
\text { treatment leading to } \\
\text { ineffective results and } \\
\text { worsening of symptoms }\end{array}$ \\
\hline$E 25^{(30)}$ & $\begin{array}{l}\text { 2017/Uganda/ } \\
\text { Web of Science/IV }\end{array}$ & $\begin{array}{l}\text { Cross } \\
\text { sectional } \\
\text { LE }=6\end{array}$ & $\begin{array}{l}\text { Difficulty following the } \\
\text { guidelines of health } \\
\text { professionals }\end{array}$ \\
\hline$E 26^{(31)}$ & $\begin{array}{l}\text { 2017/USA/Web } \\
\text { of Science/IV }\end{array}$ & $\begin{array}{l}\mathrm{RCT}^{*} \\
\mathrm{LE}=2\end{array}$ & $\begin{array}{l}\text { Patient's refusal to follow } \\
\text { the therapeutic plan }\end{array}$ \\
\hline$E 27^{(32)}$ & $\begin{array}{l}\text { 2017/China/ } \\
\text { Scopus/II }\end{array}$ & $\begin{array}{l}\mathrm{RCT}^{*} \\
\mathrm{LE}=2\end{array}$ & $\begin{array}{l}\text { Patient's refusal to follow } \\
\text { the therapeutic plan }\end{array}$ \\
\hline$E 28^{(33)}$ & $\begin{array}{l}\text { 2017/Australia/ } \\
\text { Cochrane/II }\end{array}$ & $\begin{array}{l}\text { Systematic } \\
\text { review } \\
\mathrm{LE}=1\end{array}$ & $\begin{array}{l}\text { Multifactorial and dynamic } \\
\text { process that determines } \\
\text { ineffective health control }\end{array}$ \\
\hline E29(34) & $\begin{array}{l}\text { 2016/South } \\
\text { Africa/Scopus/II }\end{array}$ & $\begin{array}{l}\text { Cohort } \\
L E=3\end{array}$ & $\begin{array}{l}\text { Patient's refusal to follow } \\
\text { the therapeutic plan }\end{array}$ \\
\hline $\mathrm{E} 30^{(35)}$ & $\begin{array}{l}\text { 2016/Zambia/ } \\
\text { Scopus/II }\end{array}$ & $\begin{array}{l}\text { Cross } \\
\text { sectional } \\
\mathrm{LE}=6\end{array}$ & $\begin{array}{l}\text { Abandonment of } \\
\text { treatment leading to } \\
\text { ineffective results and } \\
\text { worsening of symptoms }\end{array}$ \\
\hline
\end{tabular}

Chart 1 (concluded)

\begin{tabular}{|c|c|c|c|}
\hline Studies & $\begin{array}{l}\text { Year/Country/ } \\
\text { Database/Area }\end{array}$ & $\begin{array}{l}\text { Type of Study } \\
\text { / Level of } \\
\text { Evidence (LE) }\end{array}$ & Concept attributes \\
\hline $\mathrm{E} 31^{(36)}$ & $\begin{array}{l}\text { 2016/Tanzania/ } \\
\text { Scopus/II }\end{array}$ & $\begin{array}{l}\text { Descriptive } \\
\qquad \mathrm{LE}=6\end{array}$ & $\begin{array}{l}\text { Abandonment of } \\
\text { treatment leading to } \\
\text { ineffective results and } \\
\text { worsening of symptoms }\end{array}$ \\
\hline $\mathrm{E} 32^{(37)}$ & $\begin{array}{l}\text { 2016/ } \\
\text { Mozambique/ } \\
\text { Science Direct/l }\end{array}$ & $\begin{array}{l}\text { Descriptive } \\
\quad L E=6\end{array}$ & $\begin{array}{l}\text { Difficulty following the } \\
\text { guidelines of health } \\
\text { professionals }\end{array}$ \\
\hline$E 33^{(38)}$ & $\begin{array}{l}\text { 2016/USA/ } \\
\text { Scopus/II }\end{array}$ & $\begin{array}{l}\text { Cross } \\
\text { sectional } \\
\mathrm{LE}=6\end{array}$ & $\begin{array}{l}\text { Abandonment of } \\
\text { treatment leading to } \\
\text { ineffective results and } \\
\text { worsening of symptoms }\end{array}$ \\
\hline E34 ${ }^{(39)}$ & $\begin{array}{l}\text { 2017/USA/ } \\
\text { Cochrane/II }\end{array}$ & $\begin{array}{l}\text { Systematic } \\
\text { review } \\
\mathrm{LE}=1\end{array}$ & $\begin{array}{l}\text { Abandonment of } \\
\text { treatment leading to } \\
\text { ineffective results and } \\
\text { worsening of symptoms }\end{array}$ \\
\hline E35 (40) & $\begin{array}{l}\text { 2014/USA/ } \\
\text { Science Direct/II }\end{array}$ & $\begin{array}{l}\text { Cohort } \\
\mathrm{LE}=3\end{array}$ & $\begin{array}{l}\text { Patient's refusal to follow } \\
\text { the therapeutic plan }\end{array}$ \\
\hline E36 $6^{(41)}$ & $\begin{array}{l}\text { 2014/Namibia/ } \\
\text { Science Direct/I }\end{array}$ & $\begin{array}{l}\text { Descriptive } \\
\qquad \mathrm{LE}=6\end{array}$ & $\begin{array}{l}\text { Patient's refusal to follow } \\
\text { the therapeutic plan }\end{array}$ \\
\hline$E 37^{(42)}$ & $\begin{array}{l}\text { 2015/Brazil/ } \\
\text { Science Direct/IV }\end{array}$ & $\begin{array}{l}\text { Cross } \\
\text { sectional } \\
\mathrm{LE}=6\end{array}$ & $\begin{array}{l}\text { Abandonment of } \\
\text { treatment leading to } \\
\text { ineffective results and } \\
\text { worsening of symptoms }\end{array}$ \\
\hline$E 38^{(43)}$ & $\begin{array}{l}\text { 2018/Australia/ } \\
\text { Science Direct/II }\end{array}$ & $\begin{array}{l}\text { Cross } \\
\text { sectional } \\
\text { LE }=6\end{array}$ & $\begin{array}{l}\text { Difficulty following the } \\
\text { guidelines of health } \\
\text { professionals }\end{array}$ \\
\hline E39(44) & $\begin{array}{l}\text { 2016/Australia/ } \\
\text { Cochrane/II }\end{array}$ & $\begin{array}{l}\text { Systematic } \\
\text { review } \\
\mathrm{LE}=1\end{array}$ & $\begin{array}{l}\text { Abandonment of } \\
\text { treatment leading to } \\
\text { ineffective results and } \\
\text { worsening of symptoms }\end{array}$ \\
\hline $\mathrm{E} 40^{(45)}$ & $\begin{array}{l}\text { 2014/Nigeria/ } \\
\text { PubMed// }\end{array}$ & $\begin{array}{l}\text { Descriptive } \\
\qquad \mathrm{LE}=6\end{array}$ & $\begin{array}{l}\text { Difficulty following the } \\
\text { guidelines of health } \\
\text { professionals }\end{array}$ \\
\hline $\mathrm{E} 41^{(46)}$ & $\begin{array}{l}\text { 2017/Malawi/ } \\
\text { Cinahl// }\end{array}$ & $\begin{array}{l}\text { Descriptive } \\
\qquad \mathrm{LE}=6\end{array}$ & $\begin{array}{l}\text { Abandonment of } \\
\text { treatment leading to } \\
\text { ineffective results and } \\
\text { worsening of symptoms }\end{array}$ \\
\hline$E 42^{(47)}$ & $\begin{array}{l}\text { 2016/Lesotho/ } \\
\text { PubMed/I }\end{array}$ & $\begin{array}{l}\text { Descriptive } \\
\qquad \mathrm{LE}=6\end{array}$ & $\begin{array}{l}\text { Difficulty following the } \\
\text { guidelines of health } \\
\text { professionals }\end{array}$ \\
\hline $\mathrm{E} 43^{(48)}$ & $\begin{array}{l}\text { 2015/Kenya/ } \\
\text { PubMed/III }\end{array}$ & $\begin{array}{l}\text { Descriptive } \\
\qquad \mathrm{LE}=6\end{array}$ & $\begin{array}{l}\text { Abandonment of } \\
\text { treatment leading to } \\
\text { ineffective results and } \\
\text { worsening of symptoms }\end{array}$ \\
\hline$E 44^{(49)}$ & $\begin{array}{l}\text { 2013/Tanzania/ } \\
\text { Cinahl/II }\end{array}$ & $\begin{array}{l}\text { Cohort } \\
\mathrm{LE}=3\end{array}$ & $\begin{array}{l}\text { Abandonment of } \\
\text { treatment leading to } \\
\text { ineffective results and } \\
\text { worsening of symptoms }\end{array}$ \\
\hline $\mathrm{E} 45^{(50)}$ & $\begin{array}{l}\text { 2014/Dominican } \\
\text { Republic / } \\
\text { Cinahl/II }\end{array}$ & $\begin{array}{l}\text { Cohort } \\
\mathrm{LE}=3\end{array}$ & $\begin{array}{l}\text { Abandonment of } \\
\text { treatment leading to } \\
\text { ineffective results and } \\
\text { worsening of symptoms }\end{array}$ \\
\hline $\mathrm{E} 46^{(51)}$ & $\begin{array}{l}\text { 2013/Brazil/ } \\
\text { LILACS/I }\end{array}$ & $\begin{array}{l}\text { Descriptive } \\
\text { LE }=6\end{array}$ & $\begin{array}{l}\text { Difficulty following the } \\
\text { guidelines of health } \\
\text { professionals }\end{array}$ \\
\hline
\end{tabular}

Note: Area I - nursing; II - medicine; III - multidisciplinary, IV - public health and V-biological sciences. * RCT-Randomized Clinical Trial. 


\section{Critical attributes}

Attributes are components that define the concept, that is, characteristics that will determine ineffective health control in people living with AIDS. For PLWHA, their needs go beyond treating the disease and involve an entire emotional and social context that permeates the difficulties in dealing daily with situations such as depressive symptoms, stigma, discrimination, a reframing of their life history, in addition to adverse effects related to the therapeutic regimen. From the analysis, it was

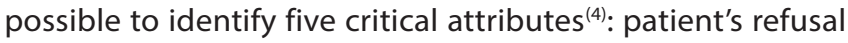
to follow the therapeutic plan $(7,9-10,13,21,23-25,27,31-32,34,37,40-41,45-46,49,51)$; abandonment of treatment leading to ineffective results and worsening of symptoms ${ }^{(8,11,14,16-17,22,26,28-29,35-36,38-39,42,44,46,48-50)}$; difficulty in reaching goals agreed between the person and the health professional $^{(6,12,15,18-20,37,43,51)}$; difficulty following the guidelines of health professionals ${ }^{(30,44-45,47)}$; multifactorial and dynamic process that determines ineffective health control ${ }^{(33)}$.

\section{Background and consequences}

The antecedents are events commonly occurred before the identification of the phenomenon and contribute to its consolidation. Consequences are identified or even predicted when there is a conjunction of factors of different natures in the presence of the phenomenon, once developed and not treated ${ }^{(4)}$. Thus, according to the terminology adopted by NANDA-I, the antecedents are characterized as the etiological factors; and the consequent ones, as defining characteristics.

The antecedents of the concept are shown in Chart 2 and its consequences in Chart 3, in association with related factors and defining characteristics, respectively, both expressed in the NANDA-I taxonomy with reference to the diagnosis "Ineffective Health Control".

Chart 2 - Background to Ineffective Health Control in People Living with AIDS ${ }^{(4)}, 2020$

\begin{tabular}{|c|c|}
\hline Background & Related factors (NANDA- I) \\
\hline Alcohol use ${ }^{(9,21,25,31,33-34,40)}$ & NM \\
\hline Side effects to medications $s^{(7,11,14,17-18,22,45)}$ & NM \\
\hline Depression ${ }^{(9,14,16,24,32-33,49)}$ & NM \\
\hline Use of illicit drugs s $^{(17,21,23,25,31,33)}$ & NM \\
\hline Stigma ${ }^{(8-9,11,20,50)}$ & NM \\
\hline Low education level $\left.\right|^{(8,14-15,31,33)}$ & NM \\
\hline Anxiety $^{(16-17,24,32-33)}$ & NM \\
\hline Financial difficulties ${ }^{(8,20,26,31,43)}$ & Perceived barrier \\
\hline Difficulty of adequate access to care $\mathrm{e}^{(7-8,12,20,33)}$ & Perceived barrier \\
\hline Lack of social support ${ }^{(7,15-16,41,49)}$ & Insufficient social support \\
\hline Forgetfulness ${ }^{(7,9,11,18)}$ & NM \\
\hline Fear of revealing the disease $\mathrm{e}^{(7,9,28)}$ & NM \\
\hline Many medicines to take ${ }^{(18-19,51)}$ & Difficulty controlling a complex treatment regimen \\
\hline Beliefs of mixing alcohol and medication ${ }^{(9-10,21)}$ & NM \\
\hline Being away from home or traveling ${ }^{(11,18,50)}$ & NM \\
\hline Religious beliefs incompatible with the therapeutic plan ${ }^{(22,28,45)}$ & NM \\
\hline Lack of support from partner and family ${ }^{(30,45-46)}$ & Insufficient social support \\
\hline Unpleasant taste of medicines ${ }^{(45,51)}$ & NM \\
\hline Lack of medication at home ${ }^{(6-7)}$ & NM \\
\hline Denial of the disease $\mathrm{e}^{(8,19)}$ & NM \\
\hline Violence from partners and family members ${ }^{(35-36)}$ & Family conflict \\
\hline Dissatisfaction with care $\mathrm{e}^{(10-11)}$ & NM \\
\hline Secret use of treatment ${ }^{(14)}$ & NM \\
\hline Lack of hope for the future ${ }^{(45)}$ & NM \\
\hline Age below 40 years ${ }^{(23)}$ & NM \\
\hline Blame $^{(8)}$ & NM \\
\hline Change in routine that makes it difficult to implement the regime ${ }^{(18)}$ & Difficulty moving through complex care systems \\
\hline Barriers between customer and provider ${ }^{(19)}$ & Perceived barrier \\
\hline Difficulty understanding the health team's guidelines ${ }^{(30)}$ & Insufficient knowledge about the therapeutic regimen \\
\hline Lack of expectations for clinical improvement ${ }^{(14)}$ & Feeling of helplessness \\
\hline Lack of scheduled appointments ${ }^{(42)}$ & NM \\
\hline Negative health beliefs incompatible with the plan ${ }^{(46)}$ & Decision conflict \\
\hline Discrimination $^{(11)}$ & NM \\
\hline Less patient involvement in treatment due to the service's low credibility ${ }^{(48)}$ & NM \\
\hline
\end{tabular}


Chart 3 - Consequences of Ineffective Health Control in People Living with AIDS ${ }^{(4)}, 2020$

\begin{tabular}{|c|c|}
\hline Consequences & Defining characteristics (NANDA-I) \\
\hline Inefficient decisions to achieve treatment goals ${ }^{(21,25,31,34)}$ & Ineffective choices in daily life to achieve health goals \\
\hline Complications associated with the development of the disease $\mathrm{e}^{(13,29,39,44)}$ & NM \\
\hline Neurological and cognitive disorders ${ }^{(13,29,39,44)}$ & NM \\
\hline Cardiovascular disorders ${ }^{(13,29,39,44)}$ & NM \\
\hline Coloproctological manifestations $s^{(13,29,39,44)}$ & NM \\
\hline Periodontal changes $(13,29,39,44)$ & NM \\
\hline Ocular manifestations $\mathbf{s}^{(13,29,39,44)}$ & NM \\
\hline Renal disorders ${ }^{(13,29,39,44)}$ & NM \\
\hline Neoplasms $s^{(13,29,39,44)}$ & NM \\
\hline Opportunistic infections ${ }^{(8,14)}$ & NM \\
\hline Tuberculosis / HIV co-infection ${ }^{(8,14)}$ & NM \\
\hline Failure in the practice of reducing risk factors ${ }^{(6-7)}$ & Failure to act to reduce risk factors \\
\hline Failure to incorporate treatment into daily life $\mathrm{e}^{(6-7)}$ & Failure to include the treatment regimen in daily life \\
\hline Development of minor mental disorders ${ }^{(27)}$ & NM \\
\hline Memory deficits ${ }^{(38)}$ & NM \\
\hline Conduct of ineffective health control(41) & NM \\
\hline Difficulty understanding the therapeutic plan ${ }^{(41)}$ & Difficulty with the prescribed regimen \\
\hline
\end{tabular}

Note: NM - No match.

\section{Identification of empirical references}

This step sought to determine the empirical references for the attributes, considered classes or categories of real phenomena that, by their existence, demonstrate the occurrence of the concept. Thus, the following empirical references were identified: interview scripts $^{(6,8,10,13,16,19-20,22,26,31,36,41,44,50)}$; questionnaires ${ }^{(9,14-15,23,25,29,43,48)}$; Questionnaire to Evaluate the Adherence to HIV Therapy (CEAT$\mathrm{VIH})^{(17-18,24,32,38,45,51)}$; focus groups ${ }^{(30,46-47)}$; pharmacy information from the health service ${ }^{(31,33,42)}$; medication count ${ }^{(21,40)}$; phone calls $^{(34)}$; and patient self-assessment ${ }^{(12)}$.

\section{Identification of the model case and the additional case}

In order to exemplify the use of the concept, a clinical case of the model type was created with the defining attributes and an additional case of the opposite type, opposing the concept.

Model case ${ }^{(4)}$ : A.G.L, 30 years old, male, studied up to the 5 th grade of elementary school. He does not use the medication correctly due to forgetfulness; he has had side effects such as dizziness, nausea and vomiting. Alcohol and drug user. Many medicines to take as well as fear of the family discovering his diagnosis, in addition to the distance from his residence to the health service, made him abandon treatment.

Otherwise ${ }^{(4)}$ : D.M.G.S, 35 years old, female, married, Catholic, diagnosed with AIDS a year ago. She reports being well and has no complaints. In laboratory tests, she has an undetectable viral load, an LT-CD4 count above 500 . She reports correct use of antiretrovirals, paying attention to the schedules and dose of medications. Go to the health service to get your medicine and have a good relationship with the health team.

\section{Identification of possible uses of the concept}

During the analysis, for the concept of Ineffective Health Control in people living with AIDS, it was possible to identify two definitions.

In the field of nursing practice, the concept revealed itself as a dynamic process that involves physical, psychological and behavioral aspects, resulting in considerable difficulties for long-term monitoring ${ }^{(45)}$, and evidenced by a pattern of regulation and integration into daily life of a therapeutic regimen for the treatment of diseases and their unsatisfactory aftermath, is to achieve specific health goals ${ }^{(10)}$.

As for the field of medicine, the definition of Ineffective Health Control was shown as the abandonment of antiretroviral therapy linked to the ineffective response to treatment, being considered a failure that increases HIV-related complications ${ }^{(7)}$, including readmission for AIDS, morbidity, mortality and drug resistance with the possibility of spreading resistant viruses ${ }^{(33)}$. In addition, it causes a lower CD4 cell count, higher levels of plasma viral RNA and delayed immune recovery, with disease progression that can lead to death ${ }^{(23,49)}$.

\section{Proposal for the concept of Ineffective Health Control in people living with AIDS}

The concept was defined as: dynamic and multifactorial process, which involves physical, psychological, behavioral and sociocultural aspects related to the difficulty in following the therapeutic plan agreed between the person/caregiver and the health professional, negatively affecting their clinical condition and quality of life, with personal, social and economic consequences for PLWHA ${ }^{(4)}$.

Thus, Figure 2 shows the representation of the studied concept, its definition, antecedents, consequences and attributes, in order to illustrate the information identified and constructed ${ }^{(4)}$. 


\begin{tabular}{|c|c|c|}
\hline 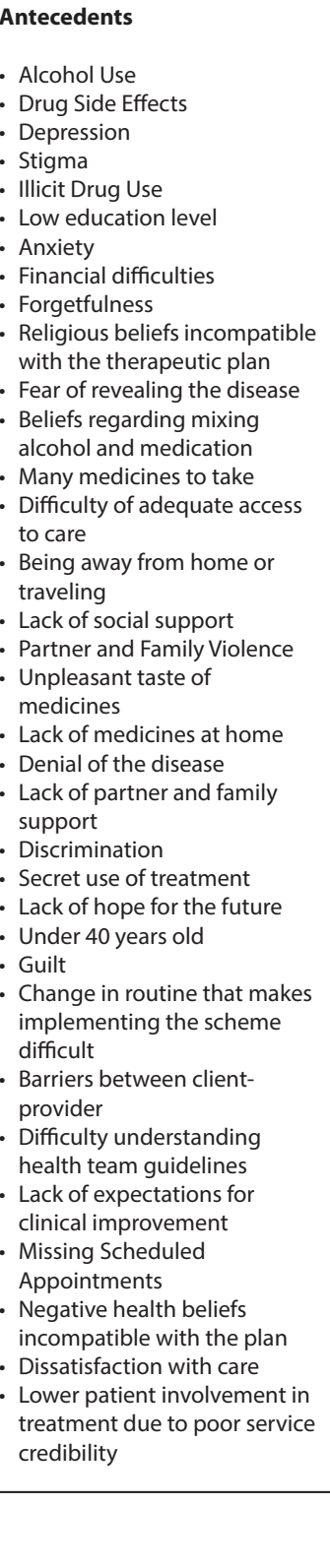 & $\begin{array}{l}\text { It is characterized by } \\
\text { Attributes } \\
\text { - Refusal of the patient } \\
\text { to follow the the } \\
\text { rapeutic plan } \\
\text { - Abandonment of } \\
\text { treatment leading } \\
\text { to ineffective results } \\
\text { and worsening of } \\
\text { symptoms } \\
\text { - Difficulty in reaching } \\
\text { agreed goals between } \\
\text { the person and the } \\
\text { health professional } \\
\text { - Difficulty following } \\
\text { health professional } \\
\text { guidelines } \\
\text { - Multifactorial and } \\
\text { dynamic process that } \\
\text { determines ineffective } \\
\text { health control }\end{array}$ & $\begin{array}{l}\text { Consequences } \\
\text { - Complications associated } \\
\text { with disease development } \\
\text { - Neurological and cognitive } \\
\text { disorders } \\
\text { - Cardiovascular disorders } \\
\text { - Coloproctological } \\
\text { manifestations } \\
\text { - Periodontal changes } \\
\text { - Eye manifestations } \\
\text { - Kidney disorders } \\
\text { - Neoplasms } \\
\text { - Opportunistic infections } \\
\text { - Tuberculosis and HIV co- } \\
\text { infection } \\
\text { - Development of minor } \\
\text { mental disorders } \\
\text { - Memory deficits } \\
\text { - Ineffective health } \\
\text { management conduct } \\
\text { - Inefficient Decisions to } \\
\text { Achieve Treatment Goals } \\
\text { Failure to practice risk factor } \\
\text { reduction } \\
\text { - Failure to incorporate } \\
\text { treatment into daily life } \\
\text { - Difficulty undestanding the } \\
\text { therapeutic plan }\end{array}$ \\
\hline
\end{tabular}

Figure 2 - Representation of the studied concept ${ }^{(4)}, 2020$

of alcohol and other drugs. However, adherence to drug therapy is essential to suppress viral replication, preventing the emergence of opportunistic infections.

When they are able to access health services, patients are faced with rigid protocols and routines that often ignore their demands. Health professionals, in turn, are also unable to listen to or apprehend the patients'life context in order to identify other health needs, limiting themselves to focusing punctually and in a fragmented way on their complaints. Even after entering the system, there are several difficulties in making appointments, complex routine examinations and consultations with specialists. Health professionals also demonstrate their weaknesses when they recognize that their academic training does not prepare for situations involving caring for PLWHA ${ }^{(19)}$.

From the background presented in Chart 2, it can be seen that, of the 34 presented, the most prevalent were: alcohol abuse, side effects and depression. Of the total number of antecedents, only 11 are correlated with NANDA-I factors ${ }^{(2)}$.

Studies carried out in South Africa have shown that alcohol use rates per capita are among the highest in the world. There are two main reasons for explaining the association between its use and the abandonment of therapy, namely: HIV-positive individuals may frequently forget to take their medications due to the influence of alcohol; and they renounce the use of antiretroviral drugs when they drink, with the belief that alcohol and antiretroviral therapy do not mix ${ }^{(34)}$.

Regarding the difficulties in adher-

\section{DISCUSSION}

As for the attributes, the search for an explanation about the patient's refusal to follow the therapeutic plan was the most prevalent, which can be understood as a personal attitude, in which each user makes their decision and create their own ways to manage their risks. In other studies ${ }^{(24)}$, it was possible to verify that the refusal is evidenced by the absences from the appointments and the failure to perform the requested exams, attitudes laden with obstacles such as contradictions, distance and the patient's refusal to accept the diagnosis of HIV/AIDS.

Adherence to the impaired therapeutic regimen is associated with the worsening of the clinical condition. This poor adherence is related to the complexity involved in the treatment, its long duration, several side effects, low educational level, consumption ing to antiretroviral therapy related to side effects, research conducted in East Africa highlights that the presence of side effects has a negative influence on antiretroviral therapy and can impact various areas of the human being, from physical to psychosocial ${ }^{(16)}$, being that depression affects the individual's ability to follow treatment.

Active use of illicit drugs among PLWHA is associated with decreased access to treatment, reduced adherence and increased mortality. Those who reported drug use ${ }^{(23)}$ were 2.6 times more likely to not adhere to therapy. Regarding financial problems, there is evidence that the employment and income situation is a significant factor associated with non-adherence to treatment. The interference of financial issues is related to the cost of transportation and poor access to health services due to the lack of free transportation ${ }^{(20)}$. 
The lack of social support can be a contributing factor for PLWHA to increase the use of tobacco, alcohol and other drugs. Research in China shows that the chances of smoking were significantly higher among PLWHAs due to stigmatizing experiences associated with the absence of social support ${ }^{(15)}$. The fear of social judgment and the fear of discrimination silence the family, which keeps the disease a secret to protect itself. Family members find limitations and/or difficulties in care and living with PLWHA, so health professionals must take care of both the person and their family ${ }^{(30)}$.

Regarding the consequences of the analyzed concept, 17 of the highest prevalence were identified, as shown in Chart 3. Of these, only four have correspondents with the defining characteristics expressed in NANDA-I ${ }^{(2)}$. Failures in adherence and abandonment of antiretroviral therapy can occur in parallel to the abandonment of clinical follow-up, including attendance at consultations, tests and any other action related to self-care.

Another explanation for the high rate of ineffective health control centers on the condition that many patients do not understand the disease and the dynamics of drug treatment. A study on the degree of adherence points out that $1.3 \%$ of the participants had low adherence (inadequate), $66 \%$ had insufficient adherence, and $32.7 \%$, strict adherence (adequate) ${ }^{(41)}$. Non-adherence is considered a complex and multidetermined phenomenon, associated with low socioeconomic levels, prescription of complex therapeutic schemes and dissatisfaction with the health service. Keeping the diagnosis secret is one of the factors that hinder adherence, because, for fear of being discovered, the patient stops following the treatment (visits to the doctor, taking medications, searching for medications, etc. (28).

Among the clinical conditions that affect people at an advanced stage of HIV infection, the most serious and most frequent are opportunistic infections. The depletion of immune cells, especially the subset of CD4 + cells, is considered a hallmark of HIV infection, as immunosuppression predisposes the individual to sexually transmitted diseases and opportunistic infections ${ }^{(14)}$.

In the case of tuberculosis (TB) patients, they require long-term treatment with various medications. And, when this diagnosis is associated with PLWHA, adherence to the therapeutic regimen becomes more difficult due to the extra burden of medication, resulting in a higher rate of default. In view of this difficulty, it is expected that new strategies are planned for monitoring the treatment ${ }^{(14)}$.

In addition, systemic complications involving the cardiovascular system increase the prevalence of this complication in PLWHA in the era of antiretroviral therapy. Study ${ }^{(29)}$ points to a higher risk in $64.8 \%$ of infected men compared to $54.8 \%$ of women.

Regarding the model case and the additional, it is important to highlight them as examples to discuss the concept of Ineffective Health Control in teaching, thus contributing to critical thinking in the process of training nurses when planning care for PLWHA. It is noteworthy that, to a large extent, difficulties arise at the beginning of treatment, when greater involvement between health professionals and patients is required. Difficulties arising from adapting to medication, daily activities and representations about treatment can be minimized with the strengthening of the bond between the parties involved and the development of qualified listening by the health professional that facilitates dialogue with the search for joint solutions and highlight coresponsibility in the treatment.

\section{Study limitations}

A limitation of the study was to include studies considered to have a low level of scientific evidence, which occurred because it was understood that it would be necessary to cover the largest number of studies, given the need to synthesize definitions and identify different elements for analyzing the concept.

\section{Contributions to the field of nursing and health}

It is hoped that the effective understanding of the use and application of the concept in question will allow its clarification and thus allow a better understanding of the phenomenon. In addition, the relevance of the contribution is in line with one of the United Nations Millennium Development Goals, related to the fight against HIV/AIDS, since the adhesion of PLWHAs to the use of antiretrovirals reduces the transmission of the virus.

Thus, it is desired that professionals can better understand the factors that lead these patients to non-adherence to treatment and, thus, can act more effectively to reduce therapeutic failures and improve the quality of life of these people.

\section{CONCLUSIONS}

The conceptual analysis made it possible to understand the multiple applications of the concept in different fields of knowledge, especially for nursing, so that the use of this concept in nurses' care practice can improve the planning of care for PLWHA, in addition to contributing with greater evidence for the Nursing Diagnosis present in the NANDA-I Taxonomy.

It was concluded that Ineffective Health Control in PLWHA is a multifactorial and dynamic process evidenced by the patient's refusal to follow a therapeutic plan, favoring treatment abandonment and, consequently, ineffective results, with worsening of symptoms and failure to reach agreed goals between the person and the health professional, which contributes greatly to the difficulties in following the guidelines of health professionals.

\section{FUNDING}

Coordination of Higher Education Personnel Improvement (Coordenação de Aperfeiçoamento de Pessoal de Nível Superior, abbreviated CAPES)

\section{ACKNOWLEDGMENT}

CAPES for contributing to this research in the form of a graduate scholarship, Master's level. To the Federal University of Rio Grande do Norte in particular the Postgraduate Program in Nursing for institutional support. 


\section{REFERENCES}

1. Ministério da Saúde(BR). Boletim Epidemiológico HIV/Aids 2019. Secretaria de Vigilância em Saúde. Departamento de Vigilância, Prevenção e Controle das Infecções Sexualmente Transmissíveis, do HIV/Aids e das Hepatites Virais [Internet]. Brasília (DF): Ministério da Saúde; 2019 [cited 2020 Jun 02]. Available from: http://www.aids.gov.br/pt-br/pub/2019/boletim-epidemiologico-de-hivaids-2019

2. Herdman TH, Kamitsuru S. NANDA International Nursing diagnoses: definitions and classification 2018-2020. 11 a ed. Oxford: Wiley Blackwell;2018.

3. Walker LO, Avant KC. Strategies for theory construction in nursing. $5^{\mathrm{a}}$ ed. Upper Saddle River: Pearson/Prentice Hall; 2011.

4. Santos WN. Análise de conceito do diagnóstico de enfermagem controle ineficaz da saúde em pessoas vivendo com Aids[Dissertação] [Internet]. Natal: Centro de Ciências da Saúde, Universidade Federal do Rio Grande do Norte; 2018[cited 2020 Jun 02]. Available from: https://repositorio.ufrn.br/handle/123456789/

5. Whittemore R, Knafl K. The integrative review: updated methodology. J Adv Nurs[Internet]. 2005[cited 2020 Jun 04];52(5):546-53. Available from: https://www.ncbi.nlm.nih.gov/pubmed/16268861

6. Moriarty K, Genberg B, Norman B, Reece R. The effect of antiretroviral stock-outs on medication adherence among patients living with HIV in Ghana: a qualitative study. J Assoc Nurses AIDS Care. 2018;29(2):231-240. doi: 10.1016/j.jana.2017.09.014

7. Tegegne AS, Ndlovu P, Zewotir T. Determinants of CD4 cell count change and time-to default from HAART; comparison of separate and joint models. BMC Infect Dis. 2018;18(1):197. doi: 10.1186/s12879-018-3108-7

8. Ahmed CV, Jolly P, Padilla L, Malinga M, Harris C, Mthethwa N, et al. Barriers to ART initiation for HIV-positive children 2-18 months in Swaziland. Afr J AIDS Res. 2018;17(2):193-202. doi: 10.2989/16085906.2018.1488266

9. Schensul SL, Ha T, Schensul JJ, et al. The role of alcohol on antiretroviral therapy adherence among persons living with HIV in Urban India. J Stud Alcohol Drugs. 2017;78(5):716-24. doi: 10.15288/jsad.2017.78.716

10. Conroy AA, McKenna SA, Leddy A. "If she is drunk, i don't want her to take it": partner beliefs and influence on use of alcohol and antiretroviral therapy in South African Couples. AIDS Behav. 2017;21(7):1885-91. doi: 10.1007/s10461-017-1697-6

11. Croome N, Ahluwalia M, Hughes LD, Abas M. Patient-reported barriers and facilitators to antiretroviral adherence in sub-Saharan Africa. AIDS. 2017;31(7):995-1007. doi: 10.1097/QAD.00000000000001416

12. Masa R, Chowa G, Nyirenda V. Chuma na Uchizi: a livelihood intervention to increase food security of people living with HIV in Rural Zambia. J Health Care Poor Underserved. 2018;29(1):349-72. doi: 10.1353/hpu.2018.0024

13. Buregyeya E, Naigino R, Mukose A. Facilitators and barriers to uptake and adherence to lifelong antiretroviral therapy among HIV infected pregnant women in Uganda: a qualitative study. BMC Pregnancy Childbirth. 2017;17(1):94. doi: 10.1186/s12884-017-1276-X

14. Guira O, Kaboré DSR, Dao G, Zagre' N, Zohoncon TM, Pietra V, et al. Prévalence de la non-observance à la trithérapie antirétrovirale et facteurs cliniques et thérapeutiques associés chez les patients à Ouagadougou (Burkina Faso). Méd Santé Tropic. 2016;26(4):396-401. doi: $10.1684 / \mathrm{mst} .2016 .0604$

15. Been SK, van de Vijver DA, Nieuwkerk PT. Risk factors for non-adherence to cART in immigrants with HIV living in the Netherlands: results from the ROtterdam ADherence (ROAD) Project. PLoS One. 2016;11(10):e0162800. doi: 10.1371/journal.pone.0162800

16. Willie TC, Overstreet NM, Sullivan TP, Sikkema KJ, Hansen NB. Barriers to HIV Medication adherence: examining distinct anxiety and depression symptoms among women living with HIV who experienced childhood sexual abuse. Behav Med. 2016;42(2):120-7. doi: 10.1080/08964289.2015.1045823

17. Nguyen NT, Tran BX, Hwang LY, Markham CM, Swartz MD, Vidrine Jl, et al. Motivation to quit smoking among HIV-positive smokers in Vietnam. BMC Pub Health. 2015;15:326. doi: 10.1186/s12889-015-1672-y

18. Saberi P, Neilands TB, Vittinghoff E, Johnson MO, Chesney M, Cohn SE. Barriers to antiretroviral therapy adherence and plasma HIV RNA suppression among AIDS clinical trials group study participants. AIDS Patient Care STDS. 2015;29(3):111-6. doi: 10.1089/apc.2014.0255

19. Coetzee B, Kagee A, Bland R. Barriers and facilitators to paediatric adherence to antiretroviral therapy in rural South Africa: a multistakeholder perspective. AIDS Care. 2015;27(3):315-21. doi: 10.1080/09540121.2014.967658

20. Portelli MS, Tenni B, Kounnavong S, Chanthivilay P. Barriers to and facilitators of adherence to antiretroviral therapy among people living with HIV in Lao PDR: a qualitative study. Asia Pac J Public Health. 2015;27(2):NP778-NP788. doi: 10.1177/1010539512442082

21. Kalichman SC, Kalichman MO, Cherry C, Hoyt G, Washington C, Greble T, et al. HIV sexual transmission risks in the context of clinical care: a prospective study of behavioural correlates of HIV suppression in a community sample, Atlanta, GA, USA. J Int AIDS Soc. 18(1):19930. doi: 10.7448/IAS.18.1.19930

22. Thielman NM, Ostermann J, Whetten $\mathrm{K}$, Whetten $\mathrm{R}$, Itemba $\mathrm{D}$, Maro V, et al. Reduced adherence to antiretroviral therapy among HIV-infected Tanzanians seeking cure from the Loliondo healer. J Acquir Immune Defic Syndr. 2014;65(3):e104-e109. doi: 10.1097/01.qai.0000437619.23031.83

23. Batista JDL, Albuquerque MFPM, Santos ML, Miranda-Filho DB, Lacerda HR, Maruza M, et al Association between smoking, crack cocaine abuse and the discontinuation of combination antiretroviral therapy in Recife, Pernambuco, Brazil. Rev Inst Med Trop. 2014;56(2):127-32. doi: 10.1590/S0036-46652014000200007 
24. Betancur MN, Lins L, Oliveira IR, Brites C. Quality of life, anxiety and depression in patients with HIV/AIDS who present poor adherence to antiretroviral therapy: a cross-sectional study in Salvador, Brazil. Braz J Infect Dis. 2017;21(5):507-14. doi: 10.1016/j.bjid.2017.04.004

25. Boni RB, Shepherd BE, Grinsztejn B, Cesar C, Cortés C, Padgett D, et al. Substance use and adherence among people living with HIV/AIDS Receiving CART in Latin America. AIDS Behav. 2016;20(11):2692-9. doi: 10.1007/s10461-016-1398-6

26. Wohl DA, Kuwahara RK, Javadi K, Kirby C, Rosen DL, Napravnik S, et al. Financial barriers and lapses in treatment and care of HIV-infected adults in a Southern State in the United States. AIDS Patient Care STDS. 2017;31(11):463-9. doi: 10.1089/apc.2017.0125

27. Lifson AR, Workneh S, Shenie T, Ayana DA, Melaku Z, Bezabih L, et al. Frequent use of khat, an amphetamine-like substance, as a risk factor for poor adherence and lost to follow-up among patients new to HIV Care in Ethiopia. AIDS Res Hum Retroviruses. 2017;33(10):995-8. doi: 10.1089/aid.2016.0274

28. Tocco JU. The Islamization of antiretroviral therapy: reconciling HIV treatment and religion in northern Nigeria. Soc Sci Med. 2017;190:75-82. doi: 10.1016/j.socscimed.2017.08.017

29. M Elicer I, Byrd D, Clark US, Morgello S, Robinson-Papp J. Motor function declines over time in human immunodeficiency virus and is associated with cerebrovascular disease, while HIV-associated neurocognitive disorder remains stable. J Neurovirol. 2018;24(4):514-22. doi: 10.1007/s13365-018-0640-6

30. Bergmann JN, Wanyenze RK, Makumbi F, Naigino R, Kiene SM, Stockman JK. Maternal influences on access to and use of infant ARVs and HIV Health Services in Uganda. AIDS Behav. 2017;21(9):2693-702. doi: 10.1007/s10461-016-1528-1

31. Cioe PA, Gamarel KE, Pantalone DW, Monti PM, Mayer KH, Kahler CW. Cigarette smoking and Antiretroviral Therapy (ART) Adherence in a sample of heavy drinking HIV-Infected men who have sex with men (MSM). AIDS Behav. 2017;21(7):1956-63. doi: 10.1007/s10461-016-1496-5

32. Tao J, Qian HZ, Kipp AM. Effects of depression and anxiety on antiretroviral therapy adherence among newly diagnosed HIV-infected Chinese MSM. AIDS. 2017;31(3):401-6. doi: 10.1097/QAD.0000000000001287

33. Gesesew HA, Ward P, Hajito KW, Feyissa GT, Mohammadi L, Mwanri L. Discontinuation from antiretroviral therapy: a continuing challenge among adults in HIV Care in Ethiopia: a systematic review and meta-analysis. PLoS One. 2017;12(1):e0169651. doi: 10.1371/journal. pone. 0169651

34. Sileo KM, Simbayi LC, Abrams A, Cloete A, Kiene SM. The role of alcohol use in antiretroviral adherence among individuals living with HIV in South Africa: event-level findings from a daily diary study. Drug Alcohol Depend. 2016;167:103-11. doi: 10.1016/j.drugalcdep.2016.07.028

35. Hampanda KM. Intimate partner violence and HIV-positive women's non-adherence to antiretroviral medication for the purpose of prevention of mother-to-child transmission in Lusaka, Zambia. Soc Sci Med. 2016;153:123-130. doi: 10.1016/j.socscimed.2016.02.011

36. Kosia A, Kakoko D, Semakafu AM, Nyamhanga T, Frumence G. Intimate partner violence and challenges facing women living with HIV/AIDS in accessing antiretroviral treatment at Singida Regional Hospital, central Tanzania. Glob Health Action. 2016;9:32307. doi: 10.3402/gha. v9.32307

37. Dawson-Rose C, Gutin SA, Cummings B, Jaiantilal P, Johnson K, Mbofana F. ART adherence as a key component of prevention with persons living With HIV in Mozambique. J Assoc Nurses AIDS Care. 2016;27(1):44-56. doi: 10.1016/j.jana.2015.10.001

38. Obermeit LC, Morgan EE, Casaletto KB, Grant I, Woods SP, HIV Neurobehavioral Research Program Group. Antiretroviral nonadherence is associated with a retrieval profile of deficits in verbal episodic memory. Clin Neuropsychol. 2015;29(2):197-213. doi: $10.1080 / 13854046.2015 .1018950$

39. Nadel J, Holloway CJ. Screening and risk assessment for coronary artery disease in HIV infection: an unmet need. HIV Med. 2017;18(4):292-9. doi: $10.1111 /$ hiv. 12422

40. Kalichman SC, Grebler T, Amaral CM, McNerney M, White D, Kalichman MO, et al. Viral suppression and antiretroviral medication adherence among alcohol using HIV Positive Adults. Int J Behav Med[Internet]. 2014 [cited 2020 Jun 03];21(5):811-20. doi: 10.1007/s12529-013-9353-7

41. Shalihu N, Pretorius L, van Dyk A, Vander Stoep A, Hagopian A. Namibian prisoners describe barriers to HIV antiretroviral therapy adherence. AIDS Care. 2014;26(8):968-75. doi: 10.1080/09540121.2014.880398

42. Nagata D, Gutierrez EB. Características dos pacientes com HIV que faltaram a consultas agendadas. Rev Saúde Pública. 2015;49:95. doi: $10.1590 /$ S0034-8910.2015049005145

43. Siefried KJ, Mao L, Cysique LA. Concomitant medication polypharmacy, interactions and imperfect adherence are common in Australian adults on suppressive antiretroviral therapy. AIDS. 2018;32(1):35-48. doi: 10.1097/QAD.0000000000001685

44. Saylor D, Dickens AM, Sacktor N. HIV-associated neurocognitive disorder-pathogenesis and prospects for treatment. Nat Rev Neurol. 2016;12(4):234-48. doi: 10.1038/nrneurol.2016.27

45. Okuboyejo S. Non-adherence to medication in outpatient setting in Nigeria: the effect of employment status. Glob J Health Sci. 2014;6(3):37-44. doi: 10.5539/gjhs.v6n3p37

46. Katirayi L, Chadambuka A, Muchedzi A, Ahimbisibwe A, Musarandega R, Woelk G, et al. Echoes of old HIV paradigms: reassessing the problem of engaging men in HIV testing and treatment through women's perspectives. Reprod Health. 2017;14(1):124. doi: 10.1186/ s12978-017-0387-1

47. Koto MV, Maharaj P. Difficulties facing healthcare workers in the era of AIDS treatment in Lesotho. SAHARA J. 2016;13(1):53-59. doi: $10.1080 / 17290376.2016 .1179588$ 
48. Mûnene E, Ekman B. Association between patient engagement in HIV care and antiretroviral therapy medication adherence: cross-sectional evidence from a regional HIV care centre in Kenya. AIDS Care. 2015;27(3):378-386. doi: 10.1080/09540121.2014.963020

49. Whetten K, Shirey K, Pence BW. Trauma history and depression predict incomplete adherence to antiretroviral therapies in a low income country. PLoS One. 2013;8(10):e74771. doi: 10.1371/journal.pone.0074771

50. Taylor BS, Reyes E, Levine EA. Patterns of geographic mobility predict barriers to engagement in HIV care and antiretroviral treatment adherence. AIDS Patient Care STDS. 2014;28(6):284-95. doi: 10.1089/apc.2014.0028

51. Motta MGC, Pedro ENR, Paula CC, Coelho DF, Ribeiro AC, Greff AP, et al. O silêncio no cotidiano do adolescente com HIV/AIDS. Rev Bras Enferm. 2013;66(3):345-50. doi: 10.1590/S0034-71672013000300007 